\title{
A NEW SPECIES OF SPHEGIGASTER SPINOLA FROM THE INDIAN SUBCONTINENT (HYMENOPTERA: CHALCIDOIDEA: PTEROMALIDAE)
}

\author{
P.M. Sureshan ${ }^{1}$ and T.C. Narendran ${ }^{2}$ \\ ${ }^{1}$ Zoological Survey of India, Western Ghats Field Research Station, Kamala Building, Annie Hall Road, Kozhikode, Kerala 673002, India. \\ ${ }^{2}$ Systematic Entomology Laboratory, Department of Zoology, University of Calicut, Kozhikode, Kerala 673635, India. \\ Email:narendra@unical.ac.in
}

\begin{abstract}
The species of Sphegigaster Spinola from the Indian Subcontinent is reviewed. A new species, Sphegigaster indica sp. nov. is described and a key to the species of Sphegigaster from the Indian Subcontinent provided.

\section{Keywords}

Hymenoptera, Pteromalidae, Sphegigaster, new species, Indian Subcontinent

Abbreviations

BMNH - The Natural History Museum, London

F 1 - Funicular segment 1 MV - Marginal vein NM - Entomologicke Oddeleni, Narodni Museum, Praha, CSSR PMV - Postmarginal vein POL - Postocellar distance SMV - Submarginal vein STV - Stigmal vein TI-T3 - Gastral tergites 1 to 3 USNM - US National Museum of Natural History, Washington D.C. ZSIC - Zoological Survey of India, Kozhikode (Calicut)
\end{abstract}

\section{Introduction}

The species of Sphegigaster Spinola are widely distributed in all parts of the world. They are parasites of Diptera mainly of Agromyzidae mining in the leaves and other soft parts of various plants. Sureshan and Narendran (1997) reviewed the Indian species of Sphegigaster. In this paper a new species of Sphegigaster is described from India. Sphegigaster brunneicornis (Ferriere) is redescribed based on the study of the lectotype in BMNH. The species of Sphegigaster from the Indian subcontinent are also keyed out.

\section{Sphegigaster indica sp. nov.}

(Figs. 1, 2)

\section{Material examined}

Holotype: Female, 19.iii. 1996, Orukomban, Parambikulam Wildlife Sanctuary, Kerala, India, Coll. P.M. Sureshan (ZSIC).

\section{Etymology}

The species is named after India, the country where it was found.

\section{Diagnostic features}

Female: Length $2.4 \mathrm{~mm}$. Head, mesosoma and petiole metallic blue; gaster blackish-brown. Legs except coxae testaceous; coxae concolrous with mesosoma. Antennae testaceous. Tegulae and veins brown; wings hyaline.

Head: Moderately reticulate, $1.1 \mathrm{x}$ as wide as mesosoma; in dorsal view width $1.7 \mathrm{x}$ length; in front view width $1.2 \mathrm{x}$ height; temple length $0.6 x$ eye length, POL $1.3 x$ OOL; malar space length $0.4 x$ eye height; eyes separated by $1.2 \mathrm{x}$ their height; clypeus with two small sharp teeth. Antennae (Fig. 1) inserted little below middle of face, scape hardly reaching median ocellus, length $0.73 x$ eye height; combined length of pedicel plus flagellum little longer than head width, Fl shorter than pedicel, funicular segments gradually decreasing in length; clava as long as 2.5 


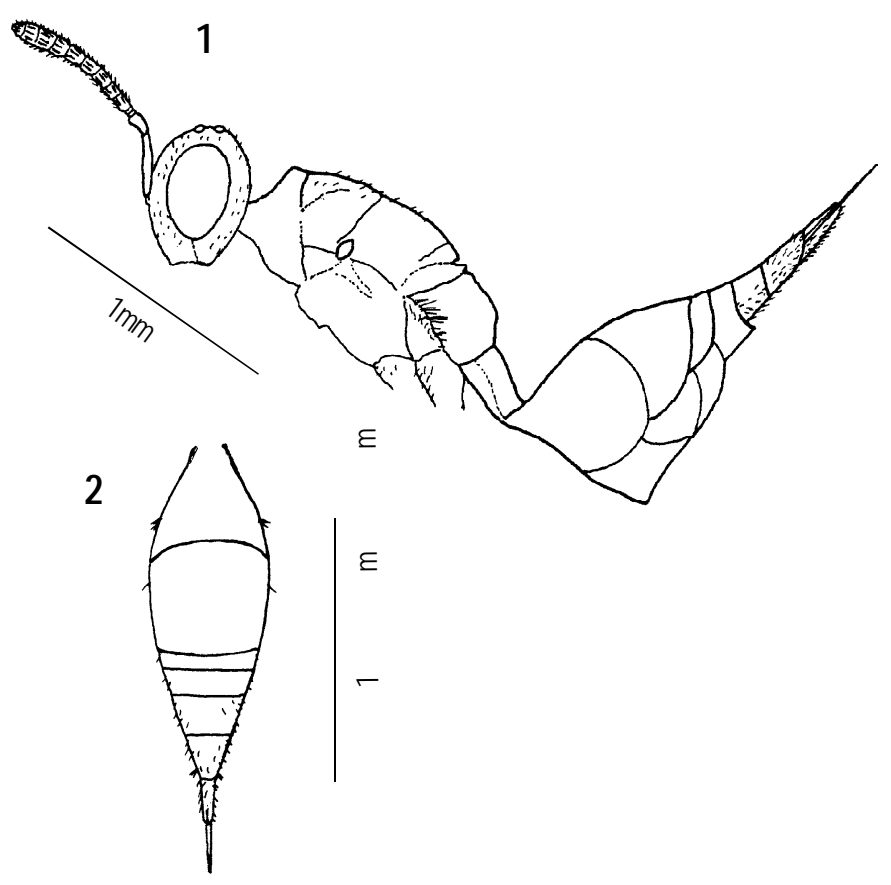

Figs. 1-2. Sphegigaster indica sp. nov. (female) 1 - Body profile; 2 - Gaster dorsal view

preceeding segments combined.

Mesosoma: Reticulate punctate with sparse white hairs; anterior margin of pronotal collar ridged, posterior smooth strip broad. Mesoscutum width 2x length; notauli appears complete. Scutellum medially as long as mesoscutum, frenum clearly marked off. Propodeum with median area strongly raised on median line; median carina strongly indicated anteriorly; basal foveae deep, spiracles small, round. Forewing length $2.4 \mathrm{x}$ width, basal part almost bare, basal hairline not indicated; marginal fringe distinct. Relative lengths: SMV 27.5, MV 16, PMV 9.5, STV 5.

Gaster: (Fig. 2) Elongate, slender; petiole short, length 1.9x width, moderately reticulate, $0.2 \mathrm{x}$ as long as rest of gaster; $\mathrm{T} 2$ only $0.3 \mathrm{x}$ as long as body of gaster.

\section{Remarks}

In general morphology and colouration, the new species resembles $S$. reticulata Sureshan and Narendran but differs from it in having a short petiole, long gastral body, propodeum with median area distinctly raised and scutellum with frenum clearly separated.

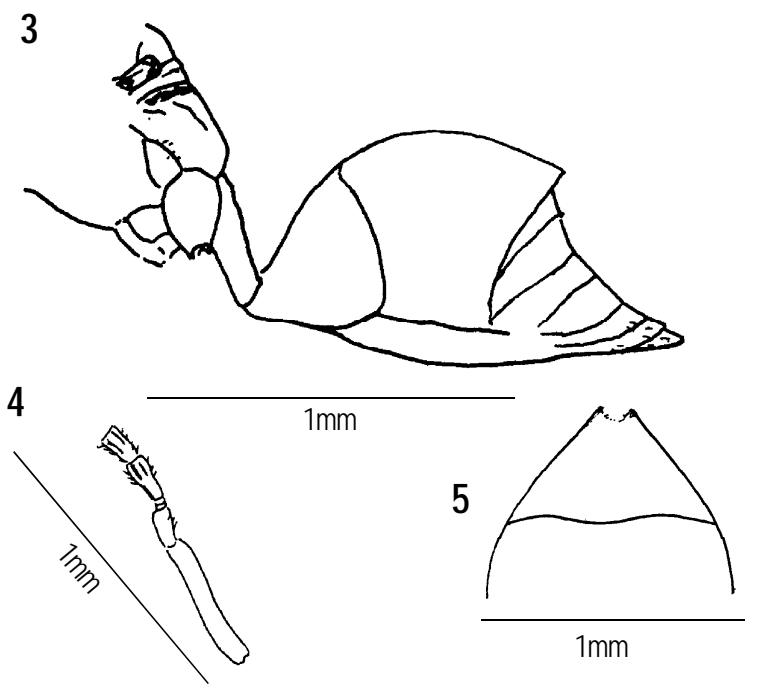

Figs. 3 -5. Sphegigaster brunneicornis (Ferriere) (female) 3 - Part of mesosoma and gaster profile; 4 - antenna basal part; 5 - basal part of gaster dorsal view

\section{Sphegigaster brunneicornis (Ferriere)}

(Figs. 3-5)

Trigonogastra brunneicornis Ferriere, 1930: 356-357. Female: Sri Lanka: Peradeniya, Lectotype (BMNH) examined. Syn. by Boucek et al., 1979.

\section{Material examined}

Lectotype: Female, 31.i.1925, Peradeniya, Ceylon, Coll. J. Hutson, ex. Pupa of Agromyza on Hibiscus esculentus (Det. Boucek, 1964) B.M. Type. Hym. 5.866.

\section{Distribution}

India: Kerala; Sri Lanka.

The species is redescribed based on the study of the lectotype.

\section{Redescription}

Lectotype: Female. Length $2.3 \mathrm{~mm}$. Body dark blue, almost black; gaster brown. Antenna with scape, pedicel and anelli clear yellow, remainder brownish-yellow. Legs clear yellow except coxae concolrous with mesosoma, mid coxae dark brown.

Head: Finely reticulate; in dorsal view width $2.2 x$ length and in front view width $1.3 x$ height; temple length $0.9 x$ eye length; POL: $\mathrm{OOL}=6.5$ : 5.5 ; eye height $1.7 \mathrm{x}$ width (in profile); malar space length $0.4 x$ eye height. Antennae (Fig. 4) inserted slightly below middle of face, scape reaching upper margin of median ocellus length $0.83 x$ eye height; Fl longer than pedicel, narrowed basally, 
funicular segments gradually becoming shorter; clava slightly longer than two preceeding segments combined.

Mesosoma: Anterior margin of pronotal collar sharp, not ridged. Mesoscutum and scutellum reticulate punctate and with scattered long hairs. Mesoscutum width 1.9x length. Scutellum medially as long as mesoscutum. Propodeum with median area little raised along median line, spiracles small, oval. Forewing length $2.24 \mathrm{x}$ width, veins very pale. Relative lengths: SMV 24.5, MV 14.5, PMV 11.5, STV 6.

Gaster: (Fig. 3) Petiole 0.31x as long as rest of gaster, finely reticulate; hind margin of TI slightly projecting; T2 large, half as long as body of gaster.

\section{Remarks}

All the Indian specimens of S. brunneicornis reported by Sureshan and Narendran, 1997 have bright body colour, forewing venation not very pale and gaster slender. This may be a case of population variation within the species.

\section{Sphegigaster stepicola Boucek (Fig. 6)}

Sphegigaster stepicola Boucek, 1965: 12-14. Male, female, CSSR: Bohemia (NM). Not examined.

Acroclisis melanagromyzae Mani, 1971: 591. Female, India: Agra (USNM). Syn. by Boucek et al., 1979. Not examined.

\section{Material examined}

Four females, 11.v.2000, Bangalore, Karnataka, India, Coll. N.G. Kumar, ex. Melanagromyza soyae (Soyabean stem fly).

\section{Distribution}

India: Kerala, Karnataka, Delhi, Bihar, Uttar Pradesh; Austria; Czechoslovakia; Moldavian SSR; Algeria. Species commonly occurs in Kerala (Sureshan \& Narendran, 1997).

6

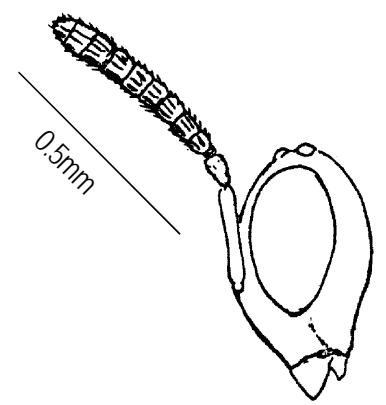

Figure 6. Sphegigaster stepicola Boucek (female) 6 - head profile
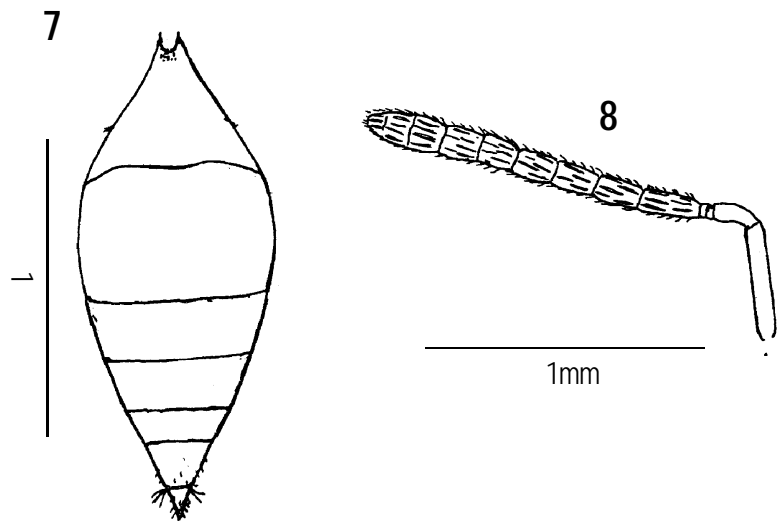

$1 \mathrm{~mm}$

Figures 7-8. Sphegigaster anamudiensis Sureshan and Narendran (female)

7 - Gaster dorsal view; 8 - Antenna

Sphegigaster anamudiensis Sureshan and Narendran (Figs. 7, 8)

Sphegigaster anamudiensis Sureshan and Narendran, 1997: 194195. Female: India: Kerala (ZSIC).

\section{Distribution}

India: Kerala. A rare species reported from Anamudi, Kerala, an high altitude habitat of southern Western Ghats, Kerala.

\section{Sphegigaster reticulata Sureshan and Narendran (Fig. 9)}

Sphegigaster reticulata Sureshan and Narendran, 1997: 195196. Female, India: Kerala (ZSIC).

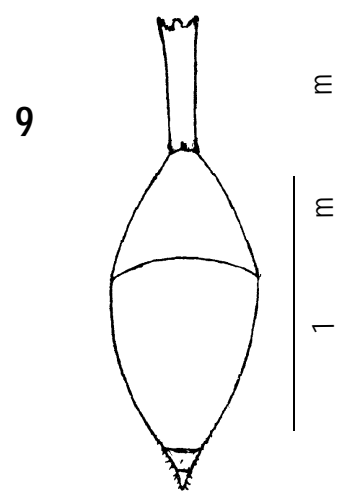

Figure 9. Sphegigaster reticulata Sureshan and Narendran (female) 9 - Gaster dorsal view 


\section{Distribution}

India: Kerala. A rare species known only from Parambikulam, a locality well known for its rich forests and wildlife in southern Western Ghats.

\section{Acknowledgements}

The first author (PMS) is grateful to the Director, Zoological Survey of India, Kolkata and the Officer-in-Charge, ZSI, Kozhikode for providing facilities and encouragement. We are also grateful to Dr. John, S. Noyes and Miss. Suzanne Lewis, BMNH, London for providing the type material of $S$. brunneicornis on loan.
References

Boucek, Z.(1965). A review of the Chalcidoid fauna of the Moldavian SSR with descriptions of new species (Hymenoptera). Acta Fauna Entomologica Musei Nationalis Pragae 11: 5-37.

Boucek, Z., S.B.R. Rao and S.I. Farooqi (1979). A preliminary review of Pteromalidae (Hymenoptera) of India and adjacent countries. Oriental Insects 12: 431-467.

Ferriere,C. (1930). Notes on Asiatic Chalcidoidea. Bulletin of Entomological Research. 21:353-360.

Mani, M.S. (1971). Some Chalcidoid parasites Hymenoptera) of leaf mining Agromyzidae (Diptera). Journal of the Natural History 591-598.

Sureshan, P.M. and T.C. Narendan (1997). Studies on Sphegigaster Spinola (Hymenoptera: Chalcidoidea: Pteromalidae) from India. Entomon 22(3 \& 4): 193-198.

\section{Key to the Sphegigaster species from the Indian subcontinent}

(Modified from Sureshan and Narendran, 1997)

1. Antennae short, all funicular segments transverse (Fig. 6), scape metallic brownish black or black ....

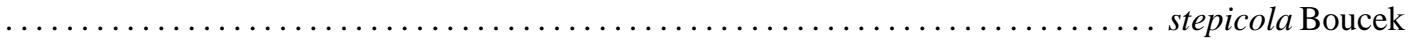

1A. Antennae long, slender, funicular segments longer than broad, scape yellow or testaceous $\ldots \ldots .2$

2. Gaster with posterior margin of $\mathrm{T} 1$ medially produced $($ Figs. 5,7$) \ldots \ldots \ldots \ldots \ldots \ldots \ldots \ldots$

2A. Posterior margin of TI not produced, straight (Figs. 2, 9) $\ldots \ldots \ldots \ldots \ldots \ldots \ldots \ldots \ldots \ldots \ldots \ldots$

3. Antennae (Fig. 8) with pedicel length $2 \mathrm{x}$ width, Fl distinctly longer than pedicel, not narrowed basally; forewing with basal hairline indicated; gaster (Fig. 7) (without petiole) distinctly longer than mesosoma

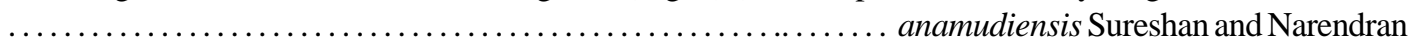

3A. Pedicel length 1.5x width; F1 little longer than pedicel (4:3), narrowed basally (Fig. 4); forewing with basal hairline not indicated; gaster not longer than mesosoma (Fig. 3) ....... brunneicornis (Ferriere)

4. Gaster (Figs. 1, 2) slender, elongate; petiole short and stout (length 2x width); T2 small, only $0.3 \mathrm{x}$ as long as body of gaster; scutellum with frenum clearly marked off, propodeum medially raised, median carina

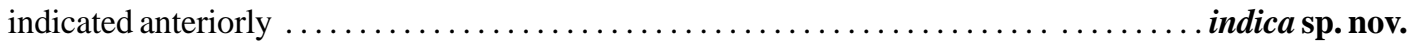

4A. Gaster (Fig. 9) not slender and elongate as above, petiole long and slender (length 3-3.8x width), T2 large, $0.6 \mathrm{x}$ as long as body of gaster; scutellum with frenum marked only on sides

reticulata Sureshan and Narendran 